\title{
FISH COMMUNITY MODELING AGENTS ON AN ARTIFICIAL REEF ON THE NORTHERN COAST OF RIO DE JANEIRO - BRAZIL
}

\author{
Daniel Shimada Brotto; Werther Krohling \& Ilana Rosental Zalmon* \\ Universidade Estadual do Norte Fluminense, Centro de Biociências e Biotecnologia \\ (Av. Alberto Lamego, 2000, 28013-602, Campos dos Goytacazes, RJ, Brasil) \\ *ilana@uenf.br
}

A B S T R A C T

Stationary visual census surveys were performed on an experimental artificial reef $\left(21^{\circ} 29^{\prime} \mathrm{S}\right.$, $\left.41^{\circ} 00^{\prime} \mathrm{W}\right)$ to clarify the role of structural complexity and benthic community as fish community modeling agents. Concrete modules of four types were grouped according to the combination of structural complexity through the presence/absence of holes and favourable/unfavourable surface for benthic colonization by anti-fouling painting. The survey (December 2002 to March 2003) showed higher abundance, richness and diversity in the complex modules. The same habitat usage pattern was observed according to vertical position and bottom type categories: demersal, hard-bottom and habitat generalist fishes preferred the complex ones. A higher number of juveniles occurred at those modules. It is assumed that trophic relationships and different habitat selection related to ontogenetic stages are also important modeling agents to the fish community structure since juvenile fish seem to actively seek the experimental complex modules.

\section{RESUMO}

Censos visuais estacionários foram realizados em um recife artificial $\left(21^{\circ} 29^{\prime} \mathrm{S}, 41^{\circ} 00^{\prime} \mathrm{W}\right)$ para determinar o papel da complexidade estrutural e da comunidade bêntica como agentes modeladores da comunidade íctica. Módulos de concreto foram agrupados de acordo com a combinação do fator complexidade estrutural através da presença/ausência de cavidades internas nos módulos e de superfícies favoráveis/desfavoráveis à colonização da comunidade bêntica através de tinta antiincrustante. De dezembro de 2002 a março de 2003, foram registrados maiores valores de abundância, riqueza e diversidade nos módulos complexos. Padrões de uso de habitat similares foram observados de acordo com a posição vertical na coluna de água e tipo de fundo: peixes demersais, de fundo consolidado e habitat generalista preferiram módulos complexos. Os resultados indicam que relações tróficas e seleção de habitat relacionada ao estágio ontogenético são também importantes agentes modeladores da comunidade íctica, uma vez que peixes juvenis buscam ativamente os módulos experimentais estruturalmente mais complexos.

Descriptors: Artificial reef, Fish community, Modeling agents, Structural complexity, Rio de Janeiro. Descritores: Recife artificial, Comunidade íctica, Agentes modeladores, Complexidade estrutural, Rio de Janeiro.

\section{INTRODUCTION}

The ecological implications of artificial reefs must be achieved in ecological researches, as they are essential to generate the knowledge for its establishment and management. The considerable efforts allocated to artificial reefs construction surpass the efforts to comprehend their ecology (Bohnsack \& Sutherland, 1985). According to Carslile et al. (1964), Sale \& Dybdahl (1975) and Ogden \& Ebersole (1981), the presence of a sessile diversified community on experimental modules increases the diversity of microhabitats, an important and necessary resource to invertebrate and fish colonization. Physical space increases the available habitat, providing food and shelter in minimum levels, which guarantees the capacity of maintaining recruitment and survival rates through the perpetuation of their populations. Sherman et al. (2002) found a positive correlation between habitat complexity, fish abundance and diversity. Ferreira et al. (2001) characterized benthic organisms as one of the reef fish community modeling factors on rocky shores. Hard bottoms of heterogeneous relief are naturally rare in the north coast of Rio de Janeiro increasing the concern for artificial reefs (Zalmon et al., 2002). It is fundamental to understand the events after artificial structures implantation to identify the ecological patterns inherent to the associated communities in order to achieve a better understanding of the usage patterns of these habitats by the fish community. The hypothesis to be tested is: if the structural complexity of the substrate and benthic community recovery are determinant factors of the reef fish community, it would be expected that an artificial reef with different availability of these variables would result in a distinct ichthyofauna related to composition, species abundance, richness and diversity. 


\section{Material And Methods}

In January 2002 an experimental reef complex was settled at $21^{\circ} 29^{\prime} \mathrm{S}, 41^{\circ} 00^{\prime} \mathrm{W}, 3.0$ miles north Rio de Janeiro state on a flat and homogeneous bottom, $9 \mathrm{~m}$ deep (Fig. 1).

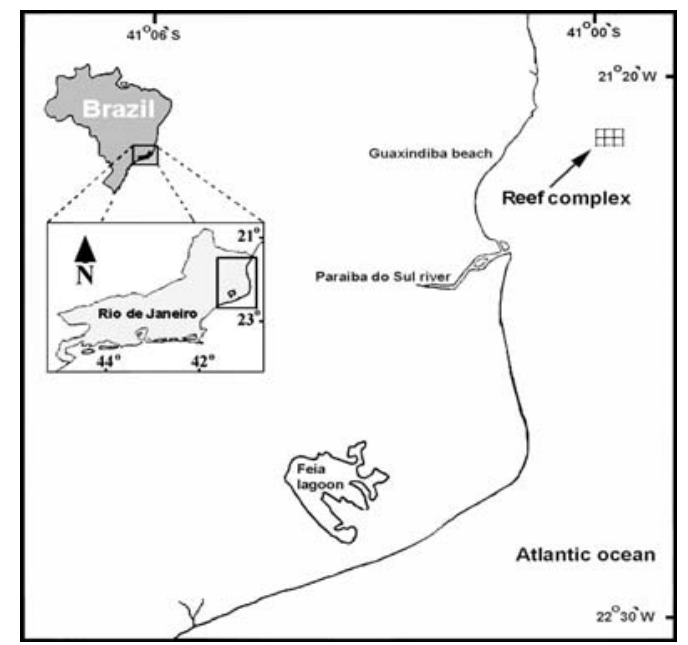

Fig. 1. Study site of the artificial reef (AR) implantation on the north coast of Rio de Janeiro.

The artificial complex comprising 36 prefabricated reef balls of four types were grouped into 12 sets according to the combination of structural complexity by the presence (WC) or absence (NC) of holes and favorable (WB) or unfavorable (NB) surface for benthic colonization with anti-fouling paint (Fig. 2).

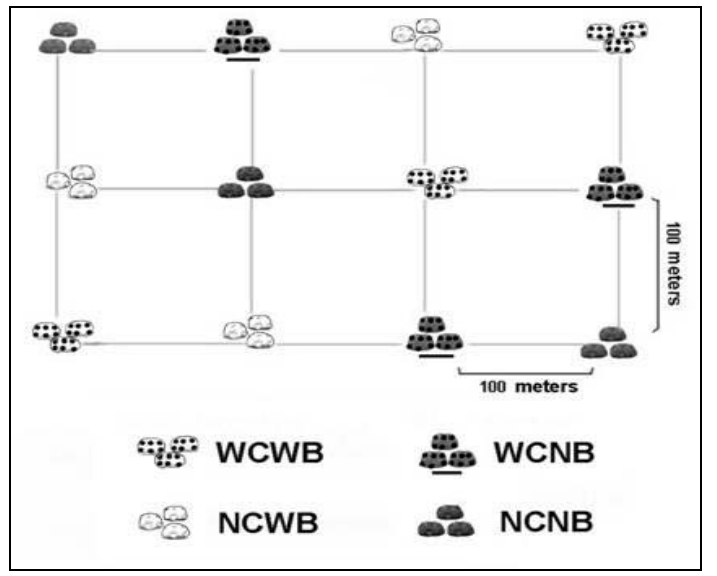

Fig. 2. Schematic drawing of the reef complex (WCWB: with complexity/with benthos, WCNB: with complexity/no benthos, NCWB: no complexity/with benthos and NCNB: no complexity/no benthos).
From December 2002 to March $2003(\mathrm{~N}=6)$ scuba divers used a non-destructive, stationary visual census method adapted from Bohnsack \& Bannerot (1986) to determine fish species richness and abundance at the concrete modules. The technique is a point count of fishes in a $6 \mathrm{~m}$ diameter cylinder, which extends from the bottom up to $6 \mathrm{~m}$ high (Fig. 3). Divers recorded all the demersal, pelagic and cryptic fishes associated to the modules and adjacent bottom. After a 5-min period of species recording, the number of fish per species and the estimated total lengths were recorded by comparing the fish size to the dimensions of a known object (ropes, diving gear or reef modules).

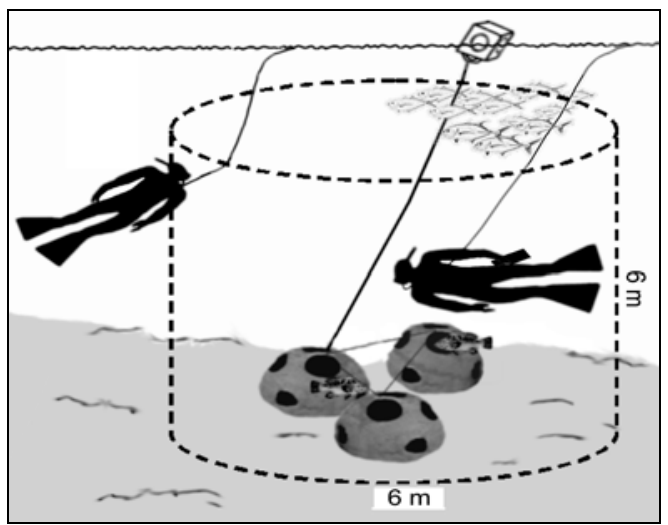

Fig. 3. Schematic representation of the sampling method.

Density, species richness and Shannon diversity were used to determine differences between fish assemblages according to each module type. Richness and density values were prior logtransformed to minimize heterocedasticity. A statistical analysis consisting of one-way ANOVA followed by a posteriori Tukey test (HSD) were used to determine the independence among sampling units and the differences among the four types of modules $(\mathrm{p}<0.05)$. A cluster analysis (UPGMA, Euclidean distance) was performed to determine the similarity between fish assemblages on the different modules.

\section{Results}

A total of 3481 fishes and 21 species were recorded during the sampling program. Fish assemblages associated to modules with structural complexity (WCWB and WCNB) presented higher densities and species richness values and two exclusive species (Cyclichthys spinosus and Acantostracium quadricornis). The fish assemblages associated to modules with no structural complexity (NCWB and NCNB) presented half the density of the most abundant species (Haemulon aurolineatum, Chaetodipterus faber and Chloroscombrus chrysurus) than in the complex ones (Table 1). 
Table 1. Species density on the different modules of the reef complex (WCWB - with complexity/with benthos, WCNB - with complexity/no benthos, NCWB - no complexity/with benthos and NCNB - no complexity/no benthos).

\begin{tabular}{|c|c|c|c|c|c|}
\hline \multicolumn{2}{|c|}{ Species } & \multicolumn{4}{|c|}{ Density (number of individuals) } \\
\hline & & WCWB & WCNB & NCWB & NCNB \\
\hline Acanthurus bahianus & Castelnau, 1855 & 17 & 5 & 8 & 0 \\
\hline Acantostracium quadricornis & Linnaeus, 1758 & 2 & 1 & 0 & 0 \\
\hline Archosargus rhomboidalis & Linnaeus, 1758 & 2 & 1 & 1 & 0 \\
\hline Caranx latus & Agassiz, 1831 & 22 & 25 & 11 & 55 \\
\hline Chaetodipterus faber & Broussonet, 1782 & 308 & 421 & 147 & 165 \\
\hline Chaetodon striatus & Linnaeus, 1758 & 11 & 5 & 2 & 0 \\
\hline Chloroscombrus chrysurus & Linnaeus, 1766 & 285 & 358 & 113 & 190 \\
\hline Cyclichthys spinosus & Cuvier, 1818 & 4 & 1 & 0 & 0 \\
\hline Gymnothorax funebris & Ranzani, 1840 & 3 & 2 & 2 & 1 \\
\hline Haemulon aurolineatum & Cuvier, 1829 & 678 & 446 & 214 & 258 \\
\hline Haemulon steindachneri & Jordan \& Gilbert, 1882 & 84 & 30 & 1 & 0 \\
\hline Halichoeres poeyi & Steindachner, 1867 & 71 & 27 & 21 & 16 \\
\hline Holocentrus adscencionis & Osbeck , 1765 & 8 & 4 & 4 & 1 \\
\hline Lutjanus annalis & Cuvier, 1828 & 21 & 17 & 2 & 4 \\
\hline Mycteroperca acutirostris & Bloch, 1793 & 23 & 15 & 1 & 3 \\
\hline Mycteroperca microlepis & Goode \& Bean, 1880 & 6 & 9 & 1 & 1 \\
\hline Orthopristis ruber & Cuvier, 1830 & 20 & 89 & 36 & 4 \\
\hline Pareques acuminatus & Bloch \& Schneider, 1801 & 19 & 8 & 5 & 4 \\
\hline Scorpaena isthmensis & Meek \& Hildebrand, 1928 & 7 & 2 & 1 & 3 \\
\hline Dules auriga & Cuvier, 1829 & 4 & 2 & 1 & 0 \\
\hline Serranus flaviventris & Cuvier, 1829 & 82 & 65 & 45 & 11 \\
\hline Total & & 1533 & 616 & 616 & 716 \\
\hline
\end{tabular}

No significant differences $(\mathrm{p}>0.05)$ were observed among sampling units of each module type placed at least $100 \mathrm{~m}$ apart, suggesting independent samples (Table 2).

Table 2. Analysis of variance (ANOVA, non significant $\mathrm{p}<$ 0.05 ) of community descriptors among sample units of each module type (WCWB - with complexity/with benthos; WCNB - with complexity/no benthos; NCWB - without complexity/with benthos; NCNB - no complexity/no benthos).

\begin{tabular}{ccccccc}
\hline \hline Types of & \multicolumn{2}{c}{ Density } & \multicolumn{2}{c}{ Richness } & \multicolumn{2}{c}{ Diversity } \\
\cline { 2 - 7 } modules & $\mathrm{F}$ & $\mathrm{p}$ & $\mathrm{F}$ & $\mathrm{p}$ & $\mathrm{F}$ & $\mathrm{p}$ \\
\hline WCWB & 0.14 & 0.87 & 2.66 & 0.10 & 2.38 & 0.13 \\
WCNB & 3.98 & 0.06 & 2.26 & 0.14 & 1.47 & 0.26 \\
NCWB & 0.24 & 0.79 & 0.19 & 0.83 & 0.36 & 0.70 \\
NCNB & 0.23 & 0.80 & 0.07 & 0.93 & 0.20 & 0.82
\end{tabular}

Abundance, species richness and diversity values were significantly higher $(p<0.05)$ on complex modules. Although differences were not statistically significant for trophic functional category, herbivorous fish occurred in higher densities at modules provided with benthic community (WCWB and $\mathrm{NCWB}$ ). Invertivorous, omnivorous and predatory fishes showed a higher association to the complex modules (Fig. 4).

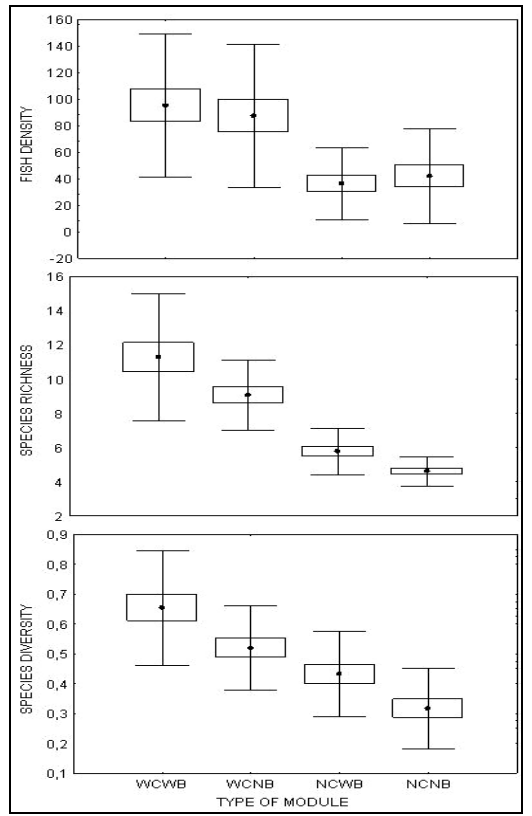

Fig. 4. Community descriptors mean values on different modules. Vertical bars and lines represent standard error and standard deviation (WCWB - with complexity/with benthos,WCNB - with complexity/no benthos,NCWB - no complexity/with benthos and NCNB - no complexity/no benthos). 
The same habitat usage pattern was observed according to vertical position on the water column and bottom type categories: demersal and hard bottom fishes plus generalists preferred the complex ones, while pelagic fish showed a homogeneous distribution (Fig. 5).
Adult and juvenile fishes presented a similar pattern of densities among module types, both presenting significant higher densities at the complex ones Fig. 6). The feeding guilds also presented higher densities at the complex modules (Fig. 7).
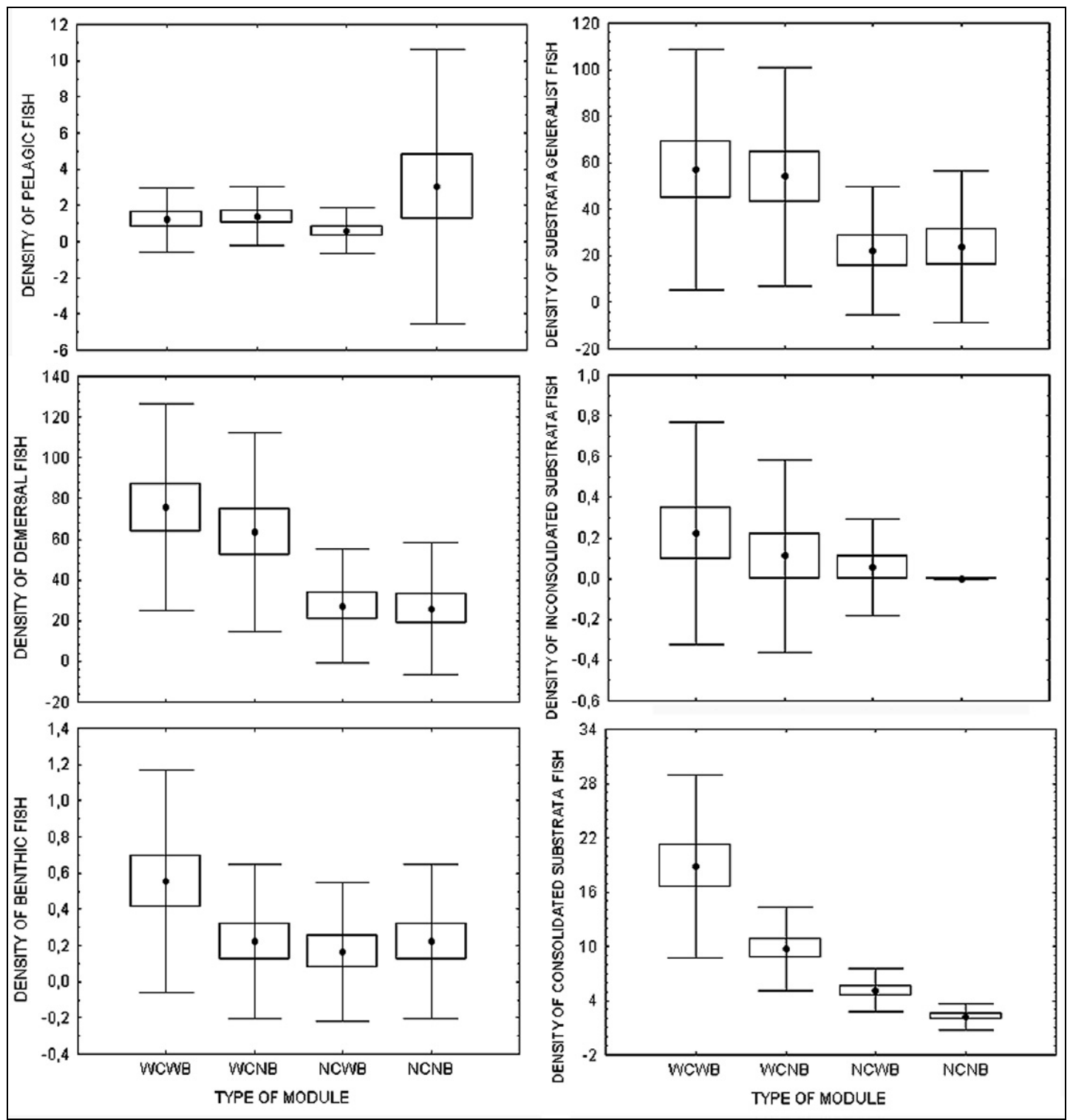

Fig. 5. Fish density mean values according to vertical position (left) and preferential substrata (right) on different modules. Vertical bars and lines represent standard error and standard deviation (WCWB - with complexity/with benthos, WCNB - with complexity/no benthos, NCWB - no complexity/with benthos and NCNB - no complexity/no benthos). 


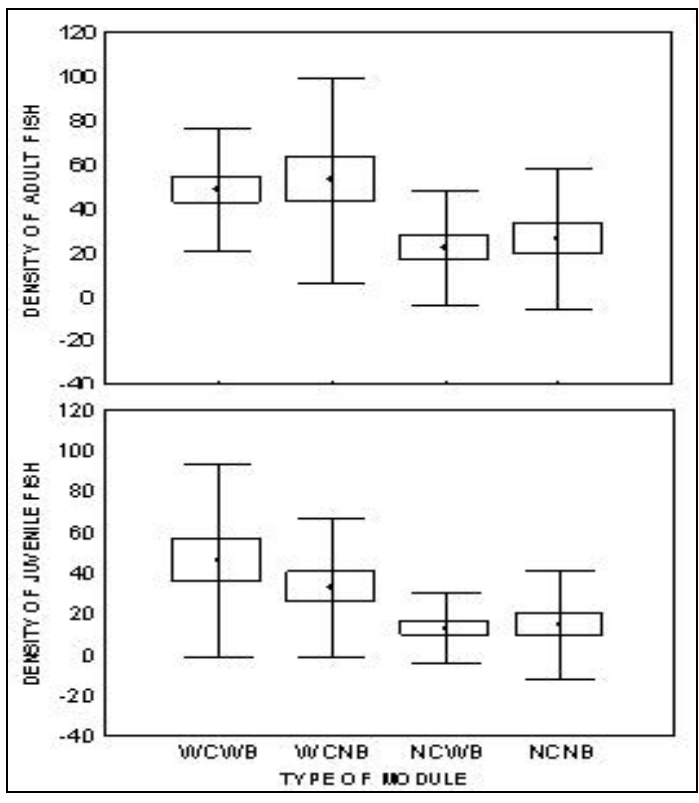

Fig. 6. Fish density mean values according to ontogenetic stages on different modules. Vertical bars and lines represent standard error and standard deviation (WCWB - with complexity/with benthos, WCNB - with complexity/no benthos, NCWB - no complexity/with benthos and NCNB - no complexity/no benthos).
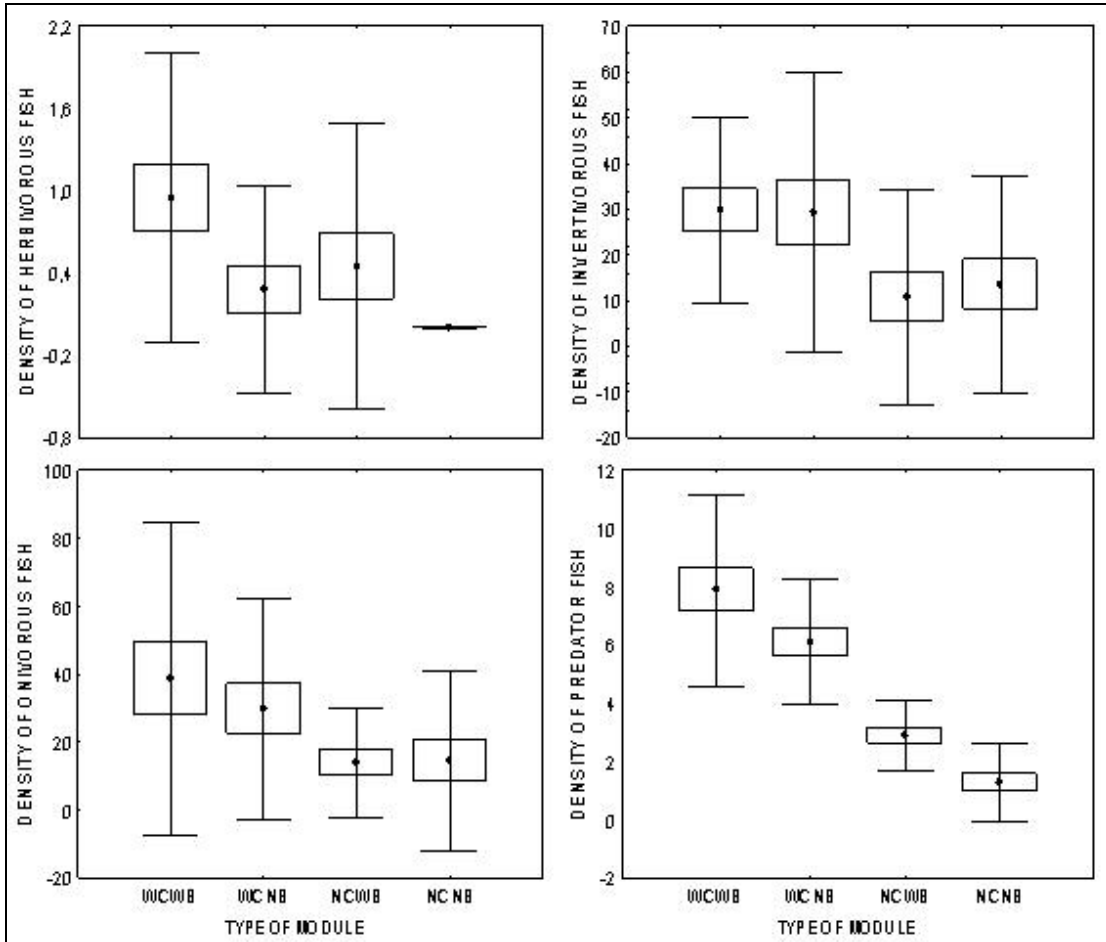

Fig. 7. Fish density mean values according to feeding habit on different modules. Vertical bars and lines represent standard error and standard deviation (WCWB - with complexity/with benthos, WCNB - with complexity/no benthos, NCW - no complexity/with benthos and NCNB - no complexity/no benthos).

Species diversity and total density showed a higher similarity among modules with structural complexity (Fig. 8). Numerical descriptors showed a clear fish association pattern to the complex modules (Fig. 8, Table 3). 


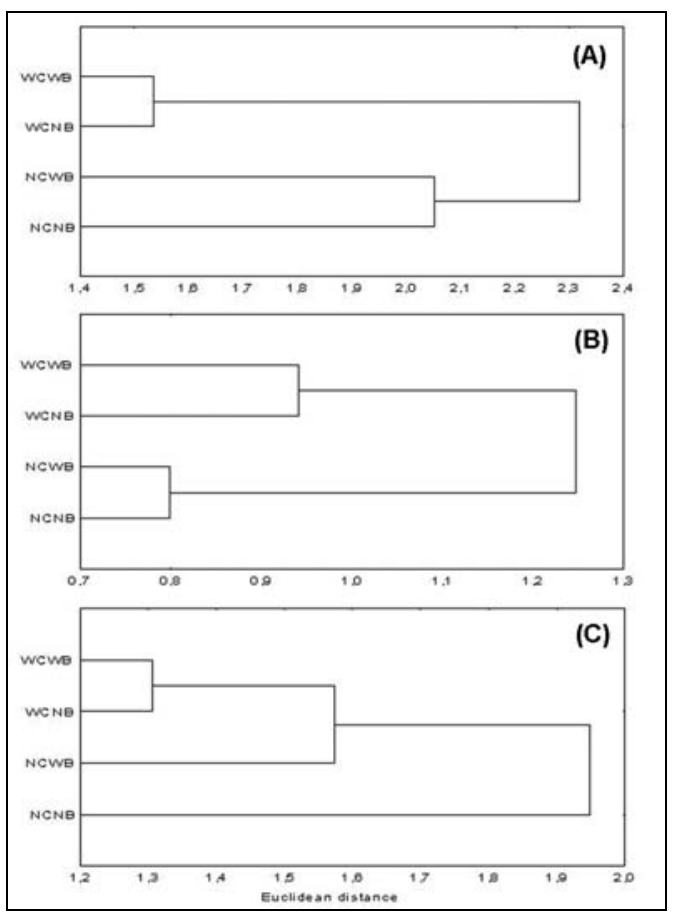

Fig. 8. Cluster analysis between modules according to specific fish density (A), species richness (B) and species diversity (C) (dissimilarity index Euclidean distance UPGMA) (WCWB - with complexity/with benthos, WCNB - with complexity/no benthos, NCWB - no complexity/with benthos and $\mathrm{NCNB}$ - no complexity/no benthos).

Table 3. Analysis of variance (ANOVA) and a posteriori Tukey test (HSD) among sample units and module types (WCWB - with complexity/with benthos; WCNB - with complexity/no benthos; NCWB - no complexity/with benthos; NCNB - no complexity/no benthos), NS: non significant $\mathrm{p}<0.05$.

\begin{tabular}{lc}
\hline \hline & Sample independence analysis \\
\hline Total density & NS \\
Species richness & NS \\
Species diversity & NS \\
\cline { 2 - 2 } Total density & Among modules analysis \\
Species richness & WCWB and WCNB $>$ NCWB and NCNB \\
Species diversity & WCWB and WCNB $>$ NCWB and NCNB \\
& WCWB $>$ WCNB, NCCB and NCNB \\
Benthic & Position in water column analysis \\
Demersal & NS \\
Pelagic & WCWB and WCNB $>$ NCWB and NCNB \\
& NS \\
Hard bottom & Preferential type of substrata analysis \\
Unhard bottom & WCWB $>$ WCNB, NCWB and NCNB \\
Generalists & NS \\
& WCWB and WCNB $>$ NCWB and NCNB \\
& Feeding habit analysis \\
Invertivorous & WCWB and WCNB $>$ NCWB and NCNB \\
Onivorous & WCWB and WCNB $>$ NCWB and NCNB \\
Herbivorous & NS \\
Predators & WCWB and WCNB $>$ NCWB and NCNB \\
& WCWB and WCNB $>$ NCWB and NCNB \\
AdultJuvenile rate & Ontogenetic stages analysis \\
Adults & Wuveniles
\end{tabular}




\section{Discussion}

Underwater visual fish census is surely the most common method for fish community assessment in reef environments (Samoilys, 1997; Seaman, 2000; Labrosse, 2002). It allows demersal, benthic and especially cryptic fish sampling in hard and heterogeneous bottoms and generates conclusive knowledge about the role of structural complexity and benthic community as reef fish assemblages modeling agents.

Other sampling methods such as gill nets or trammel nets present positive aspects since they might be applied even in extremely turbid water and allow feeding and reproductive data from fish community. The main disadvantage of this fishing gear is its selectivity for pelagic and demersal fish from homogeneous bottom (Zalmon et al., 2002; Godoy et al., 2002). Thereafter, visual census samplings would provide the knowledge about usage patterns of the habitat by reef fish communities.

The reef complex on the north coast of Rio de Janeiro showed increased structural complexity favoring higher abundance, species richness and diversity. Fish density according to vertical position, feeding habits and ontogenetic stages presented the same pattern, suggesting the shelter influence on structure and composition of the local fish assemblage. Also, in artificial reef environments Charbonnel et al. (2002), Sherman et al. (2002) and Kawasaki et al. (2003) related higher fish density and richness to higher structural complexity habitats.

Eklund (1997) in a similar experiment with fish assemblages at artificial reefs observed that fish density and richness did not differ between modules with and without benthos in opposition to those complex and non-complex.

Ferreira et al. (2001) studying fish assemblages at natural rock shores in Rio de Janeiro coast, SE-Brazil, considered the structural complexity offered by the benthic organisms as the major modeling agent to local fish community. Holbrook et al. (1990) observed that the fish assemblages are also influenced by the biogenic structural complexity of the reef referring to engineer species (Jones et al., 1997) as bivalves, balanids and polychaete, which could be understood as structural complexity generators. Jacobi \& Langevin (1994) also suggest that higher structural complexity bottoms generate superior trophic resources amounts, due to increasing microhabitats heterogeneity.

According to Luckhurst \& Luckhurst (1977), Russell et al. (1978), Brock \& Kam (1994) and Herrera et al. (2002), fish recruitment at reef environments is highly variable due to the unpredictability in production and survival of reef fish larvae, sea current dispersal patterns, and distances from larvae source areas, microhabitat requirements and predation rates. Chou et al. (1991) suggest that juvenile fishes are an important link in trophic relations of reef environments because they transfer energy from -scattered food resource as plankton to higher levels in the food chain.

Out of 57 families of Brazilian reef fish (Floeter \& Gasparini, 2000), 14 occurred in the reef complex: Acanthuridae, Serranidae, Holocentridae, Lutjanidae and Sciaenidae as juveniles and Labridae, Ephippidae, Haemulidae e Chaetodontidae as juveniles and also adults. Carangidae, Muraenidae, Diodontidae, Ostraciidae and Sparidae occurred only as adults. The main reason for the low number of reef fish family recruits might be the lack of natural reefs in the area.

Adults and juvenile fish were more abundant in complex modules since habitats of higher structural complexity represent sheltering from predation or environmental stress as the local strong bottom currents. Higher density of juveniles in complex modules suggests these modules as a proper recruitment site. Predator fish (mainly Serranidae and Lutjanidae juveniles) although not abundant in visual census sample were always associated with complex modules, where presumably they prey on invertebrates and juvenile fishes. Adults of these predator fish were not observed in the reef complex, possibly because their natural habitat is located in deeper areas as stated by Bohnsack. Bohnsack et al. (1994).

Considering the food habits, herbivorous fish did not present a clear pattern of distribution between the different modules. The four reef types were not colonized by macroalgae probably due to the low water visibility (Krohling et al., 2006). The local herbivorous fishes were surely associated to the drifted algae brought to the reef by strong bottom currents. Invertivorous fishes were the most frequent feeding category in all kind of modules, suggesting that their food requisitions were homogeneously distributed in the reef and at the adjacent bottom, where they could find abundant prey as small invertebrates of hard bottom (Frazer \& Lindberg, 1994).

These results are similar to those obtained by gill net sampling performed at the same reef complex from March 2002 to March 2003 (Brotto et al., 2006). Both techniques indicate the highest similarity for density and diversity between fish assemblages at modules with complexity and higher similarity for species richness between non-complex ones. Thereafter, structural factor plays a major role as a fish community modeling agent and benthic community a secondary one. This work indicates that trophic relations and different habitat selection according to ontogenetic stag e are also modeling factors of the 
community structure since juvenile fishes have been actively seeking the experimental complex modules.

\section{AcKnowledgements}

We would like to thank CNPq (Brazilian Scientific and Technological Development Council Proc. $\quad \mathrm{N}^{\mathrm{o}} 302303 / 2002-2$, 470093/2003-0), FAPERJ (Rio de Janeiro Research Foundation - Proc. $\mathrm{N}^{\circ}$ E26/171-046/96, E26/171-446/2000) for the financial support for this research.

\section{REFERENCES}

Bohnsack, J. A. \& Sutherland, D. L. 1985. Artificial reef research: A review with recommendations for future priorities. Bull. mar. Sci., 31:11-39.

Bohnsack, J. A. \& Bannerot, S. P. 1986. A stationary visual census technique for quantitatively assessing community structure of coral reef fishes. NOAA Tech. Rep. NMFS, 41:1-15.

Bohnsack, S. A.; Harper, D. E.; McClellan, D. B. \& Hulsberck, M. 1994. Effects of reef size on colonization and assemblage structure of fishes at artificial reefs of southern Florida, USA. Bull. mar.. Sci., 55:796-823.

Brock, R. E. \& Kam, A. H. K. 1994. Focusing the recruitment of juvenile fishes on coral reefs. Bull. mar. Sci., 55:623-630.

Brotto, D. S.; Krohling, W.; Brum, S. \& Zalmon, I. R. 2006. Usage patterns of an artificial reef by the fish community on the northern coast of Rio de Janeiro. J. coast. Res., SI 39:1277-1281

Carslile Jr, J. G.; Turner, C. H. \& Ebert, E. 1964. Artificial habitat in the marine environment. Fish. Bull., 124:1-93.

Charbonnel, E.; Serre, C.; Ruitton, S.; Harmelin, J. G. \& Jensen, A. C. 2002. Effects of increased habitat complexity on fish assemblages associated with large artificial reef units (French Mediterranean coast). ICES J. mar. Sci., 59 (Supplement):208-213.

Chou, L. M.; Lim, G. S. Y. \& Leng, C. B. 1991. An assessment of fish communities of artificial reef structures in Brunei Darussalam with recommendations for management an development. Res. Manag. Optimization, 91:15-31.

Eklund, A. M. 1997. The importance of post-settlement predation and reef resources limitation on the structure of reef fish assemblages. In: Internacional Coral Reef Symposium, 8. Paraná, 1996. Proceedings. Panamá, Smithsonian Tropical Research Inotitute, 2:1139-1142.

Ferreira, C. E. L.; Gonçalves, J. E. A. \& Coutinho, R. 2001. Community structure of fishes and habitat complexity on a tropical rocky shore. Envir. Biol. Fish., 61:353-369.

Floeter, S. R. \& Gasparini, J. L. 2000. The southwestern Atlantic reef fish fauna: composition and zoogeographic patterns. J. Fish Biol., 56:1099-1114.

Frazer, T. K. \& Lindberg, W. J. 1994. Refuge spacing similarly affects reef associated species from three phyla. Bull. mar. Sci., 55:388-400.

Godoy, E. A. S.; Almeida, T. C. M. \& Zalmon, I. R. 2002. Fish assemblages and environmental variables on an artificial reef - Rio de Janeiro, Brazil. ICES J. mar.. Sci., 59 (Supplement): 138-143
Herrera, R.; Espino, F.; Garrido, M. \& Haroun, R. J. 2002. Observations on fish colonization and predation on two artificial reefs in the Canary Islands. ICES mar. Sci., 59 (Supplement):69-73.

Holbrook, S. J.; Schmitt, R. J.. \& Ambrose, R. F. 1990. Biogenic habitat structure and characteristics of temperate reef fish assemblages. Aust. J. Ecol., 15:489503.

Jacobi, C. M. \& Langevin, R. 1994. Habitat geometry of benthic substrata: effects on arrival and settlement of mobile epifauna. J. expl. mar. Biol. Ecol., 206:39-54.

Jones, C. G.; Lawton, J. H. \& Shachak, M. 1997. Positive and negative effects of organisms as physical ecosystem engineers. Ecology, 78:1946-1957.

Kawasaki, H.; Sano, M. \& Shibuno, T. 2003. The relationship between habitat physical complexity and recruitment of the coral reef damselfish, Pomacentrus amboinensis: an experimental study using small-scale artificial reefs. Ichthyol. Res., 50:73-77.

Krohling, W.; Brotto, D. S. \& Zalmon, I. R. 2006. Fouling community recruitment on an artificial reef in the north coast of Rio de Janeiro State. J. coast. Res., SI 39:11181121.

Labrosse, P. 2002. Underwater visual fish census surveys: proper use and implementation.Noumea, New Caledonia: Secretariat of the Pacific Community, 60p.

Luckhurst, B. E. \& Luckhurst, L. 1977. Analysis of the influence of bottom variables on coral reefs communities. Mar. Biol., 49:317-323.

Ogden, J. C. \& Ebersole, J. P. 1981. Scale and community structure of coral reef fishes: a long-term study of a large artificial reef. Mar. Ecol.- Prog. Ser., 4:97-103.

Russel, B. C.; Anderson, G. R. V. \& Talbot, F. H. 1978. Seasonality and recruitment of coral reef fishes. Aust. J. mar. Freshwater Res., 28:521-528.

Sale, P. F. \& Dybdahl, R. 1975. Determinants of community structure of coral reef fishes in a experimental habitat. Ecology, 56:1343-1355.

Samoilys, M. 1997. Manual for assessing fish stocks on Pacific coral reefs. Brisbane, Australia: The State of Queensland Department of Primary Industries. 75p.

Seaman, W. 2000. Artificial reef evaluation with application to natural marine habitats. 1.ed. Boca Raton, Florida: CRC Press. 247p.

Sherman, R. L.; Gillian, D. S. \& Spieler, R. E. 2002. Artificial reef design: void space, complexity, and attractants. J. mar. Sci., 59:196-200.

Zalmon, I. R.; Novelli, R.; Gomes, M. P. \& Faria, V. V. 2002. Experimental results of an artificial reef program on the Brazilian Coast North of Rio de Janeiro. ICES J. mar. Sci., 59 (Supplement): 83-87.

(Manuscript received 06 April 2006; revised 31 July 2006; accepted 25 September 2006) 